Article

\title{
The 2017 Noneruptive Unrest at the Caldera of Cerro Azul Volcano (Galápagos Islands) Revealed by InSAR Observations and Geodetic Modelling
}

\author{
Qian Guo ${ }^{1}$, Caijun Xu ${ }^{1,2,3} \mathbb{D}$, Yangmao Wen ${ }^{1,2,3, * \mathbb{D}}$, Yang Liu ${ }^{1,2,3}$ and Guangyu Xu ${ }^{1}$ \\ 1 School of Geodesy and Geomatics, Wuhan University, Wuhan 430079, China \\ 2 Key Laboratory of Geospace Environment and Geodesy, Ministry of Education, Wuhan University, \\ Wuhan 430079, China \\ 3 Collaborative Innovation Center of Geospatial Technology, Wuhan University, Wuhan 430079, China \\ * Correspondence: ymwen@sgg.whu.edu.cn; Tel.: +86-27-6877-1610
}

Received: 8 July 2019; Accepted: 23 August 2019; Published: 23 August 2019

check for updates

\begin{abstract}
An unrest event occurred at the Cerro Azul volcano, Galápagos Islands, South America, in March 2017, leading to significant surface deformation on the southern Isabela Island, without eruption or surface rupture. We collected single-look complex synthetic aperture radar (SAR) images sensed by the Sentinel-1A satellite, obtaining eight differential interferograms, of which four showed extensive surface displacement during the co-unrest period. Geodetic data indicated that the unrest continued from 18 March to 25 March, reaching a negative peak displacement of $-32.9 \mathrm{~cm}$ in the caldera and a positive peak displacement of $41.8 \mathrm{~cm}$ on the south-east plain in the line-of-sight direction. A joint magma source deformation model, consisting of a Mogi source below the caldera and a sill source south-east of the caldera, was inverted by the Markov chain Monte Carlo method combined with the Metropolis-Hasting algorithm, acquiring the best fit with the four interferograms. The magma transport mechanism of the event was explained by magma overflowing from the compressive Mogi to the tensile sill source, resulting in the observed " $\infty$ "-shaped deformation fields. Additionally, we investigated previous events with eruption rifts and lava lakes in 1979, 1998, and 2008, and proposed a potential hazard of tectonic volcanic activity for further volcanic susceptibility research in the Cerro Azul area.
\end{abstract}

Keywords: Cerro Azul volcano; InSAR; source model; geodetic inversion; volcanic hazard

\section{Introduction}

Volcanic tectonic activity can lead to a series of volcanic eruptions and deformation events, and so understanding internal magma sources is crucial for explaining the deformation and dealing with the disaster risks [1-5]. Volcanic unrest events, including seismic activity and degassing - frequently causing surface deformation — reflect unrest patterns and disturbances from internal pressure sources [6,7]. In a conceptual model, magma sources exist under volcano craters where surface deformation rates occurring with the activity largely depend on magma supply rates and storage depths $[1,8-12]$. Surface deformation in unrest events is essential for comprehensively understanding volcanic characteristics, where geodetic observations with high precision and wide coverage provide accurate references for volcanic activity and modelling [1]. Modern geodetic techniques have been extensively developed since 1950, while advanced techniques have begun to be widely adopted for crustal and volcanic deformation monitoring, which allow us to study earthquake and volcano events at a larger and wider scale than before [13-15].

Observation from interferometric synthetic aperture radar (InSAR) is one of the most easily available data sources in modern geodetic technology and is also one of the most suitable sources for 
geodetic inversions; as such, it is commonly used in volcanic geodetic research [14,16-20]. The InSAR technique uses complex SAR data to extract surface displacement change in the line-of-sight (LOS) direction. The method depends on the phase interferometry between complex images of the same point, presenting deformation patterns on the surface with high spatial resolution [21].

An unrest event occurred in Cerro Azul volcano, Galápagos Archipelago in March 2017 [22]. Geodetic data show that the caldera subsided accompanying a large surface uplift on the south-east plain [22-24]. Neither an eruption nor a surface rupture was caused by magma source deformation during the unrest. In view of the limited number of Global Positioning System (GPS) stations on Isabela, observations from the InSAR technique provided valuable geodetic data, helping us to restore the surface deformation field during the unrest event. In this study, we collected InSAR observations from the Sentinel-1A satellite during the unrest period of the Cerro Azul volcano, recovering the surface deformation field during this event. According to the deformation characteristics, we then estimated the location and pattern parameters of the underground source deformation model and deduced the magma transport mechanism under the Cerro Azul volcano. Finally, we assessed volcanic hazard in this area by comparing magma source deformation models with records from previous eruptions.

\section{Background}

\subsection{Geological Setting}

The Galápagos Archipelago is located in the Pacific Ocean, approximately $1000 \mathrm{~km}$ from the west coast of South America, and is a part of Ecuador, South America (Figure 1). The archipelago consists of 13 major volcanic islands, on which the volcanos are all "inverted soup bowl"-shaped [14,25]. The archipelago formed on the Nazca Plate, approximately $170 \mathrm{~km}$ south of the plate edge, which is moving eastward [26-30]. Volcanism on the archipelago results from a hot spot located below Fernandina Island, north of Cerro Azul [31-34]. The eastern and western archipelago are divided by a line extending from Wolf to Alcedo on Isabela Island, where volcanoes in the western Galápagos have young structures with large bends and well-established calderas [30,31,35-38].

Isabela Island has the largest land area among the Galápagos Islands and contains six active volcanoes (Figure 1). Geodetic data show that all the volcanoes on this island except for Ecuador have experienced deformation events to different degrees in the past 20 years [39]. Previous studies based on satellite geodetic and seismic data suggested that the active volcanoes on the island have similar caldera configurations in which the deformation is mainly caused by magma intrusion or dike intrusion, circumferential caldera ring or unusual intra-caldera faulting, and irregular faults [16,39-44]. Among the volcanoes, the magmatic mechanism of the Sierra Negra volcano has been interpreted to have a layered spheroidal structure. When activity occurred, the intrusion and eruption were divided into two intervals: From the magma chamber beneath to the magma chamber above, and from the chamber above to the caldera [45]. Wolf volcano, located on northern Isabela Island, recorded lava eruption and overflowed in May 2015, when the magma was believed to have flowed through the layered dike chamber and dipping ring faults and then overflowed outward from caldera rifts. These ring-shaped faults with composite radial rifts, as well as deep trapdoors in the calderas, are common in the Wolf, Cerro Azul and Fernandina volcanoes in Galápagos [14]. Repeated unrest events without eruption occurred in Alcedo from 1992 to 2011, where three of the events were all interpreted by the magma intrusion of platform-shaped sill deformation sources underground. A sill source model was adapted in the magma system, whose inflation was the origin of two events; the third was explained by the magma propagation from the current deflation sill to a new one [6]. The uplift event in the Fernandina volcano, on Fernandina Island, was presumed to be related to an inflation of a pipe-shaped magma chamber in 2012-2013 [46].

The Cerro Azul volcano is located in southernmost Isabela Island, western Galápagos, with a height of $1640 \mathrm{~m}$ above sea level. Cerro Azul has an irregular soup-bowl-shaped caldera with a diameter of $4 \mathrm{~km} \times 5 \mathrm{~km}$ and a depth of $650 \mathrm{~m}$. It is the smallest but deepest caldera on Isabela, and it 
is also the second highest volcano on the island [47]. Previous studies have indicated that Cerro Azul has a larger and deeper caldera than other volcanos on Isabela, and it also has a deep magma system with minute extension and high temperature [20,36].

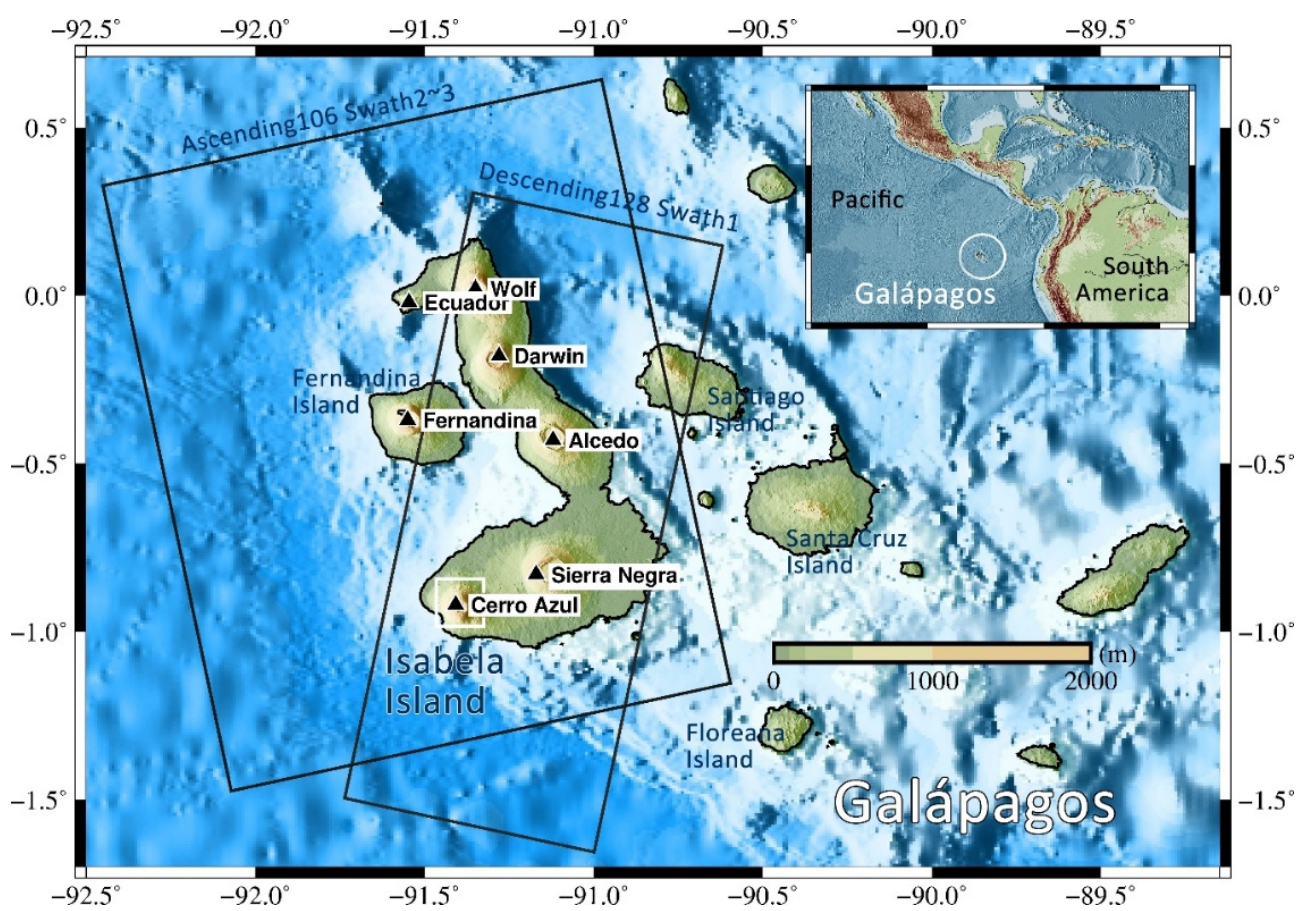

Figure 1. Topography of Isabela Island, Galápagos Archipelago. The black rectangles represent interferometric synthetic aperture radar (InSAR) data coverage. The elevation model is from the Shuttle Radar Topography Mission (SRTM) [48]. The inset map shows the location of the Galápagos in the Pacific, off the west coast of South America in the white circle.

\subsection{Recent Eruption}

Observations have confirmed that 13 deformation events have occurred at Cerro Azul since 1932, of which 11 erupted and two did not but did deform continuously for a long time [39,47]. The most recent eruptions of Cerro Azul occurred in 1979, 1998 and 2008. The latest eruption occurred from 29 May to 11 June, 2008, and was divided into two periods according to the intervals of activity. During these periods, emitted lava overflowed several times from the ring fault rim of the caldera and from radial rifts east and south-east of the caldera. Several surface rifts recorded were consistent with the rift location and lava lake flow fields in the 1998 eruption event [49].

Nine years after the latest eruption, Cerro Azul resumed unrest activity on 18 March, 2017, although no eruption occurred during this event, as usual. Internal magma in the chamber rifts did not flow to the caldera, while the resulting deformation did not cause surface rupture during the whole period of unrest. Widespread deformation began on 18 March, lasting for a week to $25 \mathrm{March}$. In a report by the Instituto Geofísico (IG), earthquakes below the caldera began to increase their seismic activity earlier on 15 February, and a 30-minute quake swarm was observed on $18 \mathrm{March}$, indicating the beginning of the volcano unrest event [23]. Swarms became more frequent after 19 March, while the activity reached its summit scale. The location of swarms migrated south-eastward and was located south-east of the caldera after 20 March, with a persistence of unrest until activity decreased on 25 March [22-24].

\section{Data and Methods}

In this paper, we used Sentinel-1A radar images transmitted by the European Space Agency (ESA), where the Sentinel-1A satellite is equipped with C-band SAR (C-SAR), divided into ascending and 
descending orbital images with a revisiting phase of 12 days each [50]. Observations on the ascending satellite orbit occur approximately 12 hours earlier than those on the descending satellite orbit in the Galápagos area. Single-look complex (SLC) images were provided by the ESA, while pre-processing and differential interferometry of images are based on the Switzerland GAMMA software [51]. The multi-look ratio of range and azimuth was set as 10:2 in processing. To avoid the phase jump in adjacent bursts, accuracy in co-registration should reach the per thousand-pixel level in the azimuth direction [52]. Therefore, a method based on topography and the enhanced spectral diversity (ESD) method was used for co-registration processing [53]. Then, the Shuttle Radar Topography Mission (SRTM) elevation model with a ground resolution of $30 \mathrm{~m}$ was used to remove the topographic contribution in the interferograms [48]. Finally, all interferograms were unwrapped using branch-cut method and geocoded to World Geodetic System 1984 (WGS84) geographic coordinates.

Due to the large amount of data produced by the high spatial resolution of InSAR observations, the quadtree down-sampling process was performed on the data set to appropriately improve the computational efficiency and retain the deformation information during inversion. The grid's variance threshold was set to $10^{-4} \mathrm{~cm}^{2}$ during the down-sampling for interferograms [54]. As a result, approximately 700,000 observations were compressed to hundreds in each interferogram. Among these observations, 1149 sampling points with the maximum number were sent to the inverting process in interferogram $\mathrm{V}$, and 108 sampling points with the minimum number were selected in interferogram III (Table 1).

Table 1. Interferogram sequence and the distinction of unrest period.

\begin{tabular}{cccccc}
\hline \multirow{2}{*}{ Interferogram Pair } & Unrest Period & \multicolumn{2}{c}{ Ascending Track 106 } & \multicolumn{2}{c}{ Descending Track 128 } \\
\cline { 3 - 6 } & & MMDD-MMDD & $\boldsymbol{B}_{\perp}{ }^{+}(\mathbf{m})$ & MMDD-MMDD & $\boldsymbol{B}_{\perp}$ (m) \\
\hline I-II & Pre-unrest & $0223-0307$ & 61.5 & $0224-0308$ & -59.8 \\
\hline III-IV & \multirow{2}{*}{ Co-unrest } & $0307-0319$ & -59.1 & $0308-0320$ & 25.6 \\
V-VI & Post-unrest & $0319-0331$ & -12.8 & $0320-0401$ & 32.8 \\
\hline VII-VIII & \multicolumn{2}{c}{$0331-0412$} & -57.2 & $0401-0413$ & 43.3 \\
\hline
\end{tabular}

The open-source geodetic Bayesian inversion software (GBIS) [17] was used in establishing the underground deformation source model, including speculating on the location and patterns of the source model. The GBIS can provide the efficient execution of volcanic source model inversion, including a series of pre- and post-processing tools with seven source models (Mogi: A point source model, McTigue: Finite spherical source model; Yang: Prolate spheroid source model; Penny: Penny-shaped sill-like source model; Sill: Horizontal rectangular sill with uniform opening model; Dike: Dipping dike with uniform opening model; and Fault: Dipping fault with uniform slip model) available for both Global Positing System (GPS) and InSAR data [17]. During the inversion, magma source location and patterns were estimated from the Markov chain Monte Carlo method combined with the Metropolis-Hastings ( $\mathrm{MH}$ ) algorithm, assuming that the errors in the data were drawn from a zero-mean Gaussian distribution $[17,55,56]$. In addition, the Bayesian approach was applied to the inversion, which contained the uncertainties of the parameter set and prior information, proposing a posterior parameter distribution to acquire the best fitting model as well as parameter uncertainties.

\section{Results}

\subsection{Surface Deformation}

Given that data with different imaging geometrics could provide more information on surface displacement fields [57-59], we collected 10 SLC images from 23 February, 2017, to 13 April, 2017, sensed from both ascending and descending mode. We performed differential interferometry for adjacent image pairs, obtaining the displacement fields in the LOS direction in an interferogram sequence from I to VIII (Table 1). According to the satellite revisit, each interferogram had a short time 
baseline of 12 days, and perpendicular baselines were short enough within $62 \mathrm{~m}$. During the event, the volcanic activity could be divided into three periods, namely: The pre-unrest period (consisting of interferograms I and II, where widespread regular deformation had not occurred among the precursor activity); the co-unrest period (consisting of interferograms III-VI, where extensive deformation was observed); and the post-unrest period (consisting of interferograms VII and VIII, where the activities had ceased).

The wrapped and unwrapped surface displacement fields of eight interferograms are shown in Figure 2 and A1, respectively, where each interferometric fringe represents the displacement of $2.8 \mathrm{~cm}$ in the LOS direction. The field around Cerro Azul presented slight inflation around the caldera, while deformation was irregular overall according to interferograms I and II. Deformation in interferogram III remained weak, while fringe characteristics could be clearly recognized, with a maximal subsidence displacement near the caldera of $-4.8 \mathrm{~cm}$ in the LOS direction. Extensive surface deformation occurred mainly on interferograms IV-VI from the caldera of the Cerro Azul volcano to the south-eastern plain, even reaching the southern coast of Isabela. Seismic data from the Global Volcanism Program (GVP) showed that the extensive deformation of Cerro Azul began on 18 March, 2017, reaching a peak of swarm activity on 21 March [22-24]. Both geodetic and seismic data indicated that swarms were not restored to daily activity until 25 March [24], and deformation ended after 31 March, when small regular interferometric fringes could be observed in the fields according to interferograms VII and VIII.

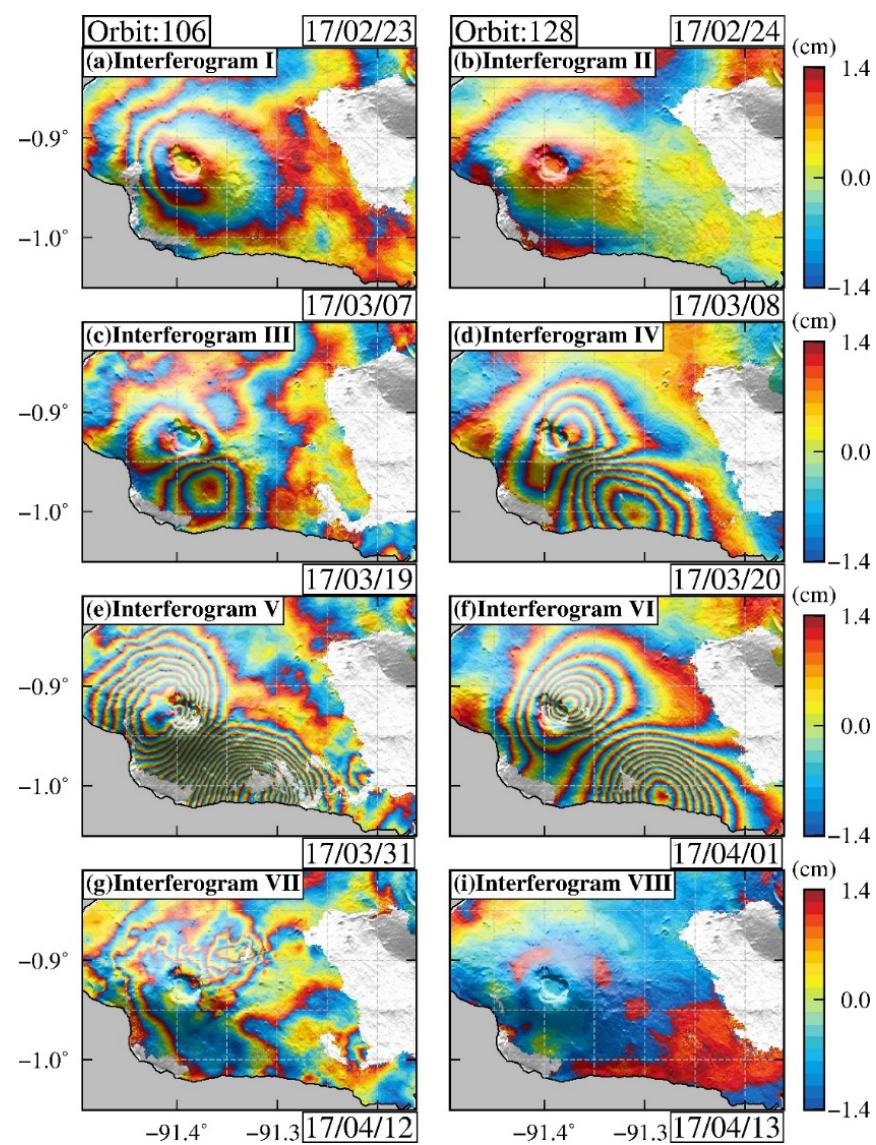

Figure 2. Wrapped surface deformation fields from Sentinel-1A satellite in the Cerro Azul volcano area from 23 February to 13 April. Every interferometric fringe indicates a displacement of $2.8 \mathrm{~cm}$ in the LOS direction. The left column shows differential interferograms from the ascending satellite observations, while the right column shows the descending observations. The top and bottom dates are the observation time for the master and slave images in pairs, respectively. 
The fringes are clearly visible with the absence of large continuous decorrelation in the major deformation area. The decorrelation region on the southern slope of Sierra Negra, deviating east from the main deformation area, is speculated as being due to the vegetation cover. The deformation field shows two central points surrounded by ring fringes forming a " $\infty$ "-shaped field, which was produced by the combination of the overall contraction and subsidence at the caldera of Cerro Azul, and the surface inflation on the south-east plain (Figure 2). The surface deformation field reached the negative peak displacement of $-32.9 \mathrm{~cm}$ near the caldera, while the positive peak displacement of $41.8 \mathrm{~cm}$ on the south-east plain between the caldera and the southern coast in the LOS direction during the whole co-unrest period; the positive displacement represents deformation toward the satellite, and the negative displacement means deformation away from the satellite (Figure A1).

The errors caused by orbital ramps and atmospheric delay in InSAR observations were often corrected by models. The most widely used method of satellite orbital ramps is to remove a best-fit plane or surface from the interferogram $[60,61]$. The atmospheric delay is mainly caused by the spatiotemporal variation in water vapor content in the atmosphere-this is called the wet tropospheric delay $[62,63]$ —and is generally considered to be topographically linearly correlated. In addition, the Generic Atmospheric Correction Online Service (GACOS) for InSAR supported by the UK Natural Environment Research Council (NERC) provides atmospheric delay models with a ground resolution of $90 \mathrm{~m} \times 90 \mathrm{~m}$ [64-66]. Here, six models were applied on the correction: A plane removing the orbit ramp, a surface removing the orbit ramp, topographic linear correlated model removing the atmospheric delay, a GACOS model removing the atmospheric delay and their combinations (Table A1). In order to quantify the effect of these correction models, we estimated the covariance (standard deviations) to semi-variograms [17] of corrected interferograms on the whole of Isabela Island (for interferograms III and V) or part of Isabela south of Alcedo volcano (for interferograms IV and VI). As the derived standard deviations were not significant (Figure A2 and Table A1), none of these corrections were used in the study.

\subsection{Geodetic Modelling}

Significant differences between the ascending and descending differential interferograms in the same revisit phase can be found in interferograms III-VI (Figure 2), which suggested that the caldera overall contracted, where the offset and positive peak values of displacement fields in the LOS direction caused by different incident angles between ascending and descending images were not distinct. Because of the different observation times between the ascending and descending images, while the deformation field showed no significant deformation before 8 March and after 1 April, we considered that the differences between interferograms III and IV were mainly caused by the different observation times, which means that intra-day displacement on 19 March directly reflected these differences. Considering that the "narrow slit" in time differed, we decided to estimate model parameters for each interferogram instead of combined phases.

Model inversion is an effective method of volcanic mechanism determination within an elastic half space [67-69]. The Mogi model is the most widely used model for inverting underground magma sources from surface deformation and is commonly used on annular fringes in deformation fields. Volcanic activity is regarded as an equivalent point source for estimating the surface displacement caused by subsurface pressure changes when the size of the magma source is much smaller than the depth of the source [70]. The Dike model with dipping dike and uniform opening based on dislocation theory can be regarded as a fault with a uniform tensile opening into which magma flows, forming the pressure source [71]. The Sill model is a special condition of the Dike model, which means that Sill is established only when the dip angle of the fault plane is zero. Under this condition, the magma chamber presents the characteristics of horizontal extension and vertical tensile opening, while circular surface deformation field fringes appear. However, the ellipse-shaped field caused by a Sill source deformation model is particularly different from that caused by a Mogi model, which shows uniform 
ring-shaped deformation field fringes without any anisotropy with double rotational symmetry on the surface.

The deformation fields (Figure 2) show that there were two deformation centers in this event located at and near the caldera and on the plain south of the caldera. These features were inconsistent with a simple source deformation models. Therefore, we considered a joint model inversion consisting of two simple magma source deformation models to estimate location and pattern parameters based on interferograms III-VI in the co-unrest period. Here, a point Mogi model and a long rectangular platform-shaped Sill model were jointly used in recovering the surface deformation field in this study, where the combination obtained the best fit for this event after several simulation experiments. The Mogi model was applied to circular subsidence around the caldera, while the Sill model was applied to the inflation field over the south-eastern plain, which led to an elliptical ring-shaped deformation field extending from the caldera south-east to the island coast, showing significant anisotropy with a west-north-west to east-south-east major axis. It should be noted that the inversion took no account of the topography, as the topography changes could be regarded as small value compared with the source depth.

The joint source deformation model achieved a good fit in recovering surface displacement fields for this event at Cerro Azul from 7 March to 1 April (Figure 3 and Table 2), where the boundary values of each parameter represent a $97.5 \%$ confidence interval. In addition, we show a comparison between modelling surface deformation and actual observations in interferograms III-VI in the co-unrest period (Figure 3). In order to distinguish the residuals, the deformation field was wrapped, and every interferometric fringe in Figure 3 represents a displacement of $2.8 \mathrm{~cm}$ in the LOS direction. The residuals and the root-mean-square (RMS) of each interferogram are shown in Figure $3 c, f, i, 1$.
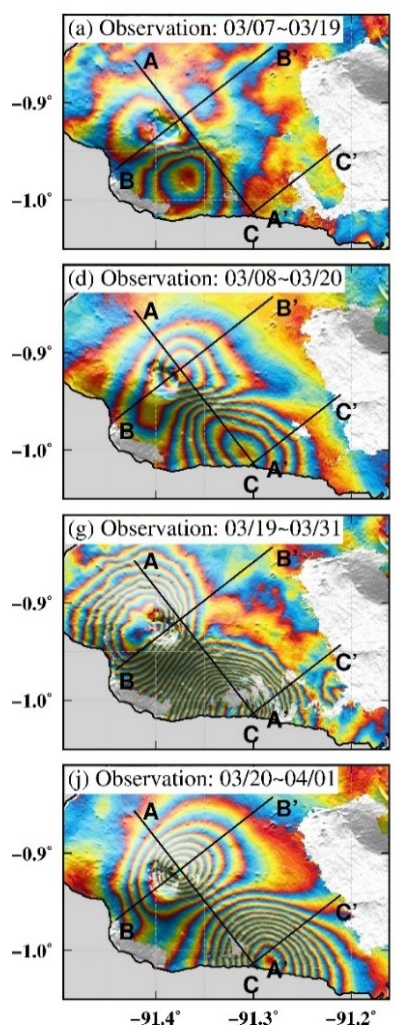
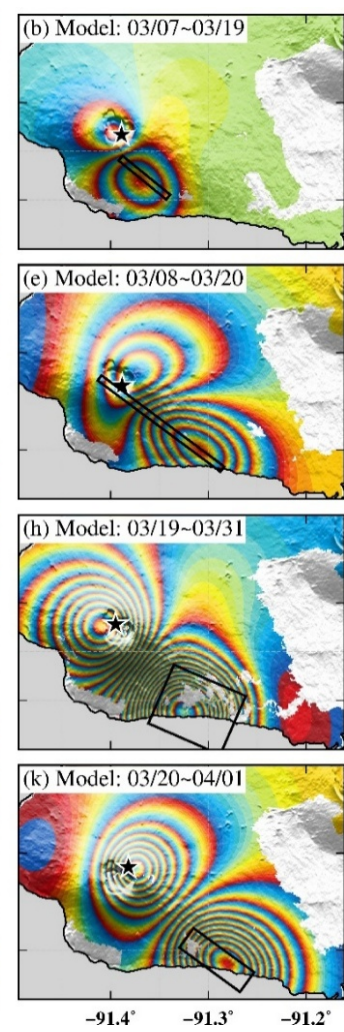
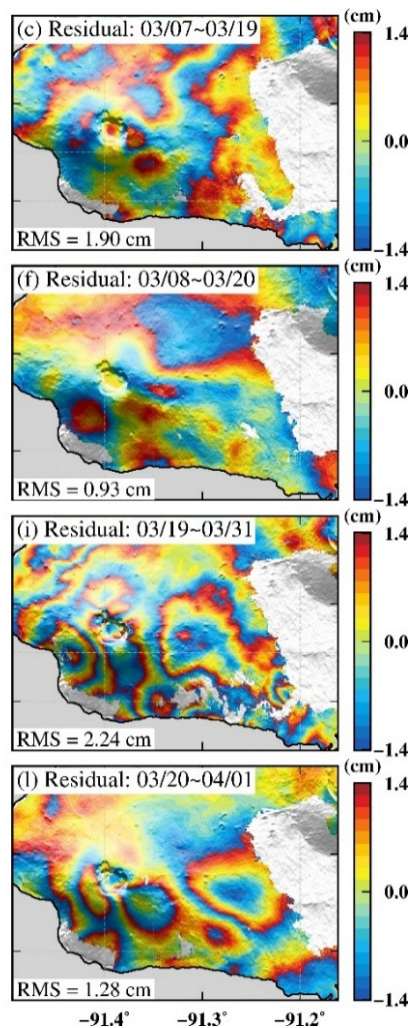

Figure 3. Deformation observed by the Sentinel-1A satellite and simulated by the joint deformation source model in interferograms III-VI. Each fringe represents the displacement of $2.8 \mathrm{~cm}$ in the LOS direction. The locations of the Mogi and Sill models projected onto the surface are drawn with black pentacles and rectangles, respectively. Three profiles, A-A', B-B' and C-C', through the positive and negative displacement regions are shown in Figure 4. 
Table 2. Parameters of joint deformation source models for interferograms III-IV.

\begin{tabular}{|c|c|c|c|c|c|c|c|c|}
\hline \multirow{2}{*}{ Interferogram Pair } & Mogi & \multirow{2}{*}{$\begin{array}{c}\text { Longitude } \\
\left({ }^{\circ}\right)\end{array}$} & \multirow{2}{*}{$\begin{array}{c}\text { Latitude } \\
\left({ }^{\circ}\right)\end{array}$} & \multirow{2}{*}{$\begin{array}{c}\begin{array}{c}\text { Depth } \\
(\mathrm{m})\end{array} \\
\begin{array}{c}\text { Depth } \\
(\mathrm{m})\end{array}\end{array}$} & \multirow{2}{*}{$\begin{array}{c}\begin{array}{c}\text { Volume } \\
\left(\mathrm{m}^{3}\right)\end{array} \\
\begin{array}{c}\text { Length } \\
(\mathrm{m})\end{array}\end{array}$} & \multirow[b]{2}{*}{$\begin{array}{l}\text { Width } \\
\text { (m) }\end{array}$} & \multirow[b]{2}{*}{$\begin{array}{c}\text { Strike } \\
\left({ }^{\circ}\right)\end{array}$} & \multirow[b]{2}{*}{$\begin{array}{l}\text { Opening } \\
\text { (m) }\end{array}$} \\
\hline & Sill & & & & & & & \\
\hline III & $3.7 \sim 3.19$ & $\begin{array}{c}-91.3889 \\
{[-91.3914 /-91.3863]} \\
-91.3675 \\
{[-91.3697 /-91.3659]}\end{array}$ & $\begin{array}{c}-0.9332 \\
{[-0.9349 /-0.9309]} \\
-0.9798 \\
{[-0.9832 /-0.9790]} \\
\end{array}$ & $\begin{array}{c}3203 \\
{[2933 / 3502]} \\
4810 \\
{[4500 / 5062]}\end{array}$ & $\begin{array}{c}-3.34 \times 10^{6} \\
{\left[-3.78 \times 10^{6} /-2.78 \times 10^{6}\right]} \\
7010 \\
{[7002 / 7191]}\end{array}$ & $\begin{array}{c}709 \\
{[642 / 1091]}\end{array}$ & $\begin{array}{c}129 \\
{[112.0 / 140.0]}\end{array}$ & $\begin{array}{c}1.29 \\
{[0.85 / 11.30}\end{array}$ \\
\hline IV & $3.8 \sim 3.20$ & $\begin{array}{c}-91.3882 \\
{[-91.3909 /-91.3784]} \\
-91.3504 \\
{[-91.3527 /-91.3341]}\end{array}$ & $\begin{array}{c}-0.9339 \\
{[-0.9366 /-0.9287]} \\
-0.9755 \\
{[-0.9877 /-0.9741]} \\
\end{array}$ & $\begin{array}{c}5952 \\
{[5687 / 7042]} \\
5772 \\
{[5366 / 6387]}\end{array}$ & $\begin{array}{c}-3.58 \times 10^{7} \\
{\left[-4.11 \times 10^{7} /-2.51 \times 10^{7}\right]} \\
17419 \\
{[12900 / 18131]}\end{array}$ & $\begin{array}{c}733 \\
{[405 / 876]}\end{array}$ & $\begin{array}{c}127 \\
{[122.8 / 130.2]}\end{array}$ & $\begin{array}{c}2.46 \\
{[1.93 / 4.11]}\end{array}$ \\
\hline $\mathrm{V}$ & $3.19 \sim 3.31$ & $\begin{array}{c}-91.3949 \\
{[-91.4028 /-91.3903]} \\
-91.3246 \\
{[-91.3551 /-91.3033]}\end{array}$ & $\begin{array}{c}-0.9221 \\
{[-0.9308 /-0.9160]} \\
-1.0400 \\
{[-1.0725 /-1.0374]} \\
\end{array}$ & $\begin{array}{c}5976 \\
{[5186 / 7497]} \\
5363 \\
{[5128 / 7831]}\end{array}$ & $\begin{array}{c}-4.37 \times 10^{7} \\
{\left[-6.54 \times 10^{7} /-3.29 \times 10^{7}\right]} \\
8932 \\
{[3794 / 9092]}\end{array}$ & $\begin{array}{c}7287 \\
{[2728 / 10121]}\end{array}$ & $\begin{array}{c}114 \\
{[147.0 / 177.6]}\end{array}$ & $\begin{array}{c}0.88 \\
{[0.80 / 3.52]}\end{array}$ \\
\hline VI & $3.20 \sim 4.1$ & $\begin{array}{c}-91.3823 \\
{[-91.3836 /-91.3809]} \\
-91.2951 \\
{[-91.2950 /-91.2891]}\end{array}$ & $\begin{array}{c}-0.9135 \\
{[-0.9153 /-0.9124]} \\
-1.0134 \\
{[-1.0181 /-1.0103]}\end{array}$ & $\begin{array}{c}4450 \\
{[4221 / 4778]} \\
6623 \\
{[6491 / 7084]}\end{array}$ & $\begin{array}{c}-1.92 \times 10^{7} \\
{\left[-2.18 \times 10^{7} /-1.72 \times 10^{7}\right]} \\
8985 \\
{[7904 / 8966]}\end{array}$ & $\begin{array}{c}1184 \\
{[985 / 1380]}\end{array}$ & $\begin{array}{c}124 \\
{[119.8 / 133.8]}\end{array}$ & $\begin{array}{c}3.62 \\
{[3.20 / 4.65]}\end{array}$ \\
\hline
\end{tabular}


To further evaluate the fitness of the joint model, we selected three profiles-A-A', B-B' and $\mathrm{C}-\mathrm{C}^{\prime}$; profile $\mathrm{A}-\mathrm{A}^{\prime}$ on the surface connects the area with a negative peak displacement near the caldera and the area with a positive peak displacement on the south-eastern plain, and B- $\mathrm{B}^{\prime}$ and $\mathrm{C}-\mathrm{C}^{\prime}$ are perpendicular to A-A' (Figure 4). Good consistency between the observed and modelled displacement was exhibited, especially at the positive and negative peak values, except in interferogram III, as insufficient pressure of the magma chamber was provided in the earlier co-unrest period before 19 March, when a tiny displacement occurred (Table 2). The consistency of both ascending and descending images confirmed the feasibility of the magma transportation mechanism analysis based on the simulated joint deformation model.
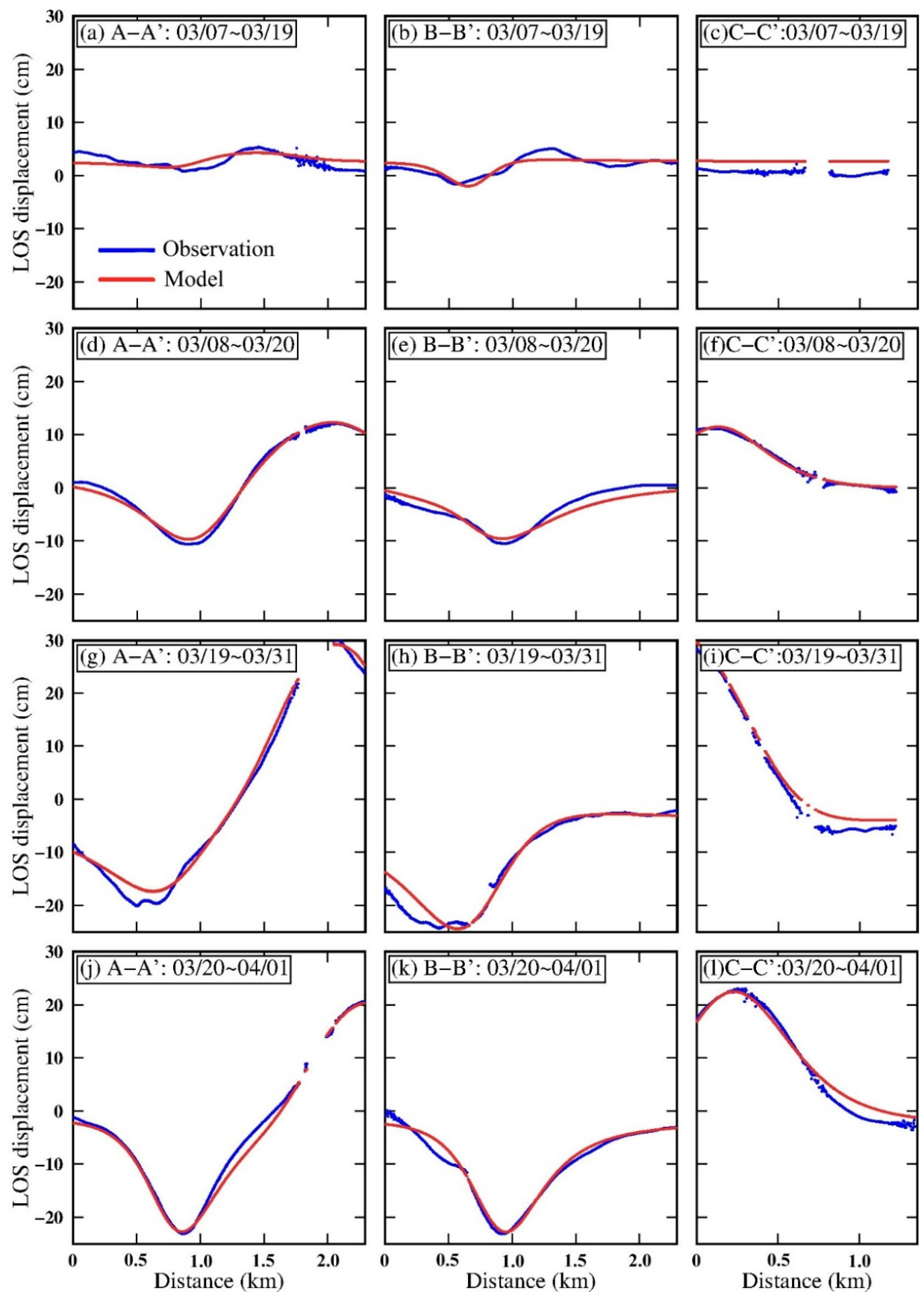

Figure 4. Comparisons of observed and modelled displacements on profiles. 


\section{Discussion}

\subsection{Interpretation of Four Interferograms in Co-Unrest Period}

After the unrest occurred, the Centre for the Observation and Modelling of Earthquakes, Volcanoes and Tectonics (COMET) first proposed a set of observations from geodetic satellites and seismometers on 27 March, speculating a source model for this event [22,23,72]; the IG in Ecuador subsequently proposed supplementary data on 6 April [24]. The locations and patterns of the joint model in this study are consistent with the report calculated by the Sentinel-1A satellite from 8 March to 20 March [23,72].

Through Sentinel-1A observations, the surface deformation field associated with the Cerro Azul volcanic unrest activity was restored, and the location and pattern parameters of the underground joint source deformation model were inverted. Next, we speculated on the status and changes in the joint model in different interferograms. In the pre-unrest period, the caldera was surrounded by continuous weak activity. More InSAR satellite observations from the COMET [72] showed a weak contraction of the caldera between 30 January and 12 February, and then expansion between 12 February and 8 March. The weak activities of contraction and expansion, which were recurrent several times surrounding the caldera, may be regarded as the topographical linear correlated phase delay, rather than a precursor to strong volcanic activity.

The inversion results of the joint source deformation model for the four interferograms in the co-unrest period indicate that the surface displacement fields of the Cerro Azul unrest event can be well simulated by a point source Mogi model and a long rectangular platform source Sill model, which extended from the southern caldera to the positive peak displacement area on the south-eastern plain during the earlier co-unrest period. The Mogi source below the caldera had a depth of 3-4 km below sea level (bsl), and the Sill model below the south-eastern plain had a depth of 4-5 km bsl with a length of $7 \mathrm{~km}$ in interferogram III. In interferogram IV, the Mogi had a depth of 5-6 km bsl, while the Sill model had an approximately similar depth yet a longer length of $17 \mathrm{~km}$. The widths of the two Sill models were both around $0.7 \mathrm{~km}$, and they exhibited long pipe shapes on the surface projection in these two interferograms.

The location and pattern of the Sill changed greatly in the later co-unrest period, which became a square rectangular platform shape instead of a long pipe shape. The square-shaped Sill had a length and width of $9 \mathrm{~m} \times 7 \mathrm{~km}$ in interferogram V and $9 \mathrm{~m} \times 1.2 \mathrm{~km}$ in interferogram VI. Considering the confidence interval of model parameters, the depth of inversion models always has a larger uncertainty; neither Mogi nor Sill revealed prominent migration through the earlier co-unrest to the later co-unrest period, whose depth was within 4-6 km. Here we speculate that the Sill transferred south-eastward and deformed from a long pipe shape to a square-shaped rectangle through the earlier co-unrest period to the later co-unrest period, where flowing magma diffused into a larger area underground.

\subsection{Conceptual Model for Unrest Event}

Based on previous research in the Galápagos Archipelago, the Cerro Azul volcano has an irregular soup-bowl-shaped caldera, and the younger structure here produced a type of caldera similar to those of other volcanoes in the western Galápagos, which have deep trapdoors and potential ring faults with surrounding radial rifts $[6,14,16,20,43,73]$. Above all, magma systems with small volumes and great depths occur in these structures [6,20,30]. According to the joint deformation model in Section 5.1, Cerro Azul tends to possess a peculiar structure with two composite causal deformation sources at the similar depth on Galápagos Archipelago.

The Mogi and the Sill sources always produced a similar depth in the collected interferograms at approximately $5 \mathrm{~km}$ bsl (Table 2). The Mogi model was adjacent to the north-west endpoint of the Sill source in interferograms III and IV, while the Sill deformed into a square and transferred south-eastward with magma continually delivered from Mogi to the square Sill in interferograms V and VI. Thus, we reasonably speculated on the transport mechanism of underground magma. The unrest deformation event was generated by the contraction of the Mogi magma source below the caldera, 
with the expansion and cracking of the south-eastern Sill magma source. Pressure was given from the internal Mogi by accumulated magma to the south-east dyke, bringing on the magma discharge of the Mogi chamber and resulting in the overall contraction of the Cerro Azul caldera and surface subsidence of the surrounding area. Meanwhile, the long rectangular platform-shaped Sill source connected its north-west endpoint with the adjacent Mogi, directing the deflated magma through cracks and rifts and delivering the magma to the south-eastern plain, causing extensive inflation on the surface. This continued throughout the whole co-unrest period even after the transference of the Sill, as the ancient Sill pipe inflation ceased in the earlier unrest period and served as the magma corridor, connecting the Mogi and the fresh Sill in the later co-unrest period.

One piece of proof of the speculation is that the volume of magma lost from the Mogi source should be equal to the increased volume of the Sill source when the assumption was established. The absolute differences between the Mogi and Sill volume changes in the four interferograms are listed in Table 3, where the ratios are calculated by the difference in the absolute magma volume change in the Mogi and Sill sources divided by the absolute magma volume change in the Sill source. In these four inversion models, ratios for interferograms IV and V are close to zero, while ratios of models for interferograms III and VI do not exceed 0.5, which supports the speculation.

Table 3. Volume changes for the Mogi and Sill sources in the inversion models.

\begin{tabular}{|c|c|c|c|}
\hline Interferogram Pair & $\begin{array}{c}V C_{M}^{\dagger} \\
\left(\mathrm{m}^{3}\right)\end{array}$ & $\begin{array}{c}V C_{S} \ddagger \\
\left(\mathrm{m}^{3}\right)\end{array}$ & $\begin{array}{c}D V C / V C_{S} \\
-\end{array}$ \\
\hline III & $3.34 \times 10^{6}$ & $6.39 \times 10^{6}$ & 0.478 \\
\hline IV & $3.58 \times 10^{7}$ & $3.15 \times 10^{7}$ & 0.137 \\
\hline $\mathrm{V}$ & $4.37 \times 10^{7}$ & $5.71 \times 10^{7}$ & 0.235 \\
\hline VI & $1.92 \times 10^{7}$ & $3.84 \times 10^{7}$ & 0.500 \\
\hline
\end{tabular}

${ }^{+}$Absolute volume changes of the Mogi source in models. ${ }^{\ddagger}$ Absolute volume changes of the Sill source in models.

$\S$ Ratio of volume change divided by absolute volume change of the Sill.

To concretely describe the system of the underground magma source and the process of magma delivery in the joint source deformation model at Cerro Azul, we drew a schematic diagram (Figure 5) of the joint model of the vertical profile $A-A^{\prime}$ in Figure 3. The diagram shows the three stages of the unrest event. Surface deformation fields in interferogram I and II with interferometric fringes centered on the caldera, which denied the origin of the magma being pumped into the Mogi just prior the co-unrest. According to the unrest cycle of a volcano, the point-shaped Mogi chamber accumulated magma from the deeper crust and asthenosphere during the long period of inter-unrest after the last eruption in 2008 and the pre-unrest period before 23 February in interferograms I and II through diminutive tectonic activities at Cerro Azul (Figure 5a).

In the earlier co-unrest period, overpressure in the magma chamber was sufficient to overcome the resistance of the surrounding rocks triggering magma flow into a dyke. Consequently, the pressure in the magma chamber was reduced, with the magma withdrawn from the chamber leading to a magma chamber deflation. The magma sought an outlet in the south-east dyke, pouring out under the pressure. Magma flowing over made up the long pipe-shaped Sill, where the dyke appeared to be fragile or rift distributed, which led to the tension of the Sill. The north-western adjacent endpoint of the Sill became the delivering hinge between the contracting Mogi and extending Sill in the earlier co-unrest period (Figure 5b).

Several days after the first intrusion in this event, magma overflowed to an extensive area underground, when the ancient Sill in the earlier co-unrest period was no longer tensile, yet it transferred into the corridor of magma delivered from the Mogi to the fresh Sill in the later co-unrest period (Figure 5c). In this period, the fresh Sill source appeared to be a square rectangular shape instead of a long pipe, while the fresh tensile area tended to transported south-eastward underground. 
(a) inter-unrest \& pre-unres

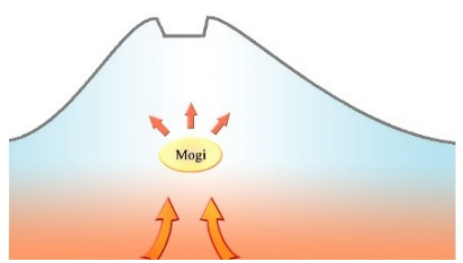

(b) earlier co-unrest

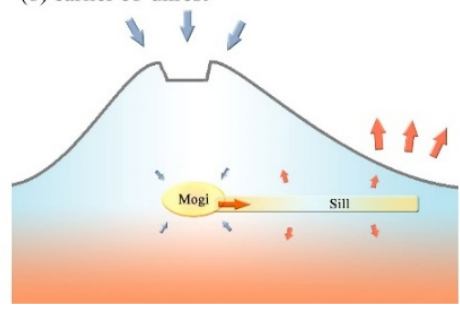

(c) later co-unrest

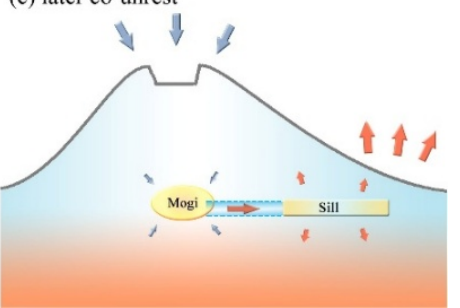

Figure 5. Schematic diagram of magma delivery in the magma model along profile A-A'. (a) Magma upwelled and accumulated in the Mogi chamber during the long period of inter-unrest and pre-unrest. (b) The Mogi source contracted while the Sill source inflated in the co-unrest period in interferograms III and IV, and magma was delivered from Mogi to Sill through the adjacent rifts. (c) The Mogi source contracted continually while the Sill source inflated, diffused and deformed in the co-unrest period in interferograms V and VI, while the remains of the ancient Sill channel served as corridor of magma delivery.

\subsection{Volcanic Hazard}

Two eruptions of Cerro Azul occurred in September 1998 and May 2008, which were recorded in detail by the GVP [47]. In the subsequent eruption incident from 29 May to 11 June, 2008, magma spewed out from the caldera and radial rifts near the caldera on the eastern slope; 40 swarm events involved were recorded within only seven hours after the eruption, among which the largest quake had a magnitude of $\mathrm{M}_{\mathrm{W}}$ 3.7. Later, on 1 June, the eruption was suspended; then, after a day of rest, lava emerged through wide rifts on the farther east slope, where the terrain is flatter than near the caldera, which produced an extensive lava lake fed by flowing lava [39]. From 15 September to 21 October, 1998, a volcanic eruption continued for 36 days, and seven plumes were observed in total. A lava lake covered $16 \mathrm{~km}^{2}$ of the area with an equivalent compact rock volume attaining $54 \mathrm{~km}^{3}$ [74,75]. Earlier, in February 1979, Cerro Azul also erupted and was accompanied by volcanic unrest lasting for several weeks [76].

Figure 6 shows the locations of the rifts on the slope east and south-east of the caldera in the above events, as well as the lava traces from every eruption above, observed or speculated. Comparing earlier events with the unrest event occurring in March 2017, several facts can be cited. First, three periods of severe tectonic activity have occurred in Cerro Azul in the last 20 years at time intervals of approximately nine years. Second, four radial magma rifts have spewed lava on the ridge and flank, and all the rifts have been located on the east to south-east side of the volcano and distributed radially. Rift locations in previous events were close to the projected position of the Sill magma source on the surface estimated for this unrest event. In addition, eruption events occurred in 1979, 1998 and 2008 in Cerro Azul, but the 2017 unrest took place nine years after the latest eruption without leading to any magma eruption or surface rupture. Whether this lack is a sign of activity reduction in Cerro Azul is still unknown.

According to the past two events in 1998 and 2008, only one eruption occurred from the caldera in Cerro Azul, but three lava eruptions were recorded from rifts on the eastern and south-eastern slopes. Eruptions occurring on slopes, rather than from the caldera or surrounding ring faults, are rare in volcanic activity. The structure of Cerro Azul has been confirmed to be similar to those of other volcanoes on the island with a deep caldera, irregular internal annular faults within the caldera, and dense radial rifts around the caldera [14,16]. Additionally, Cerro Azul has the deepest volcanic caldera and the densest radial rifts on the island $[20,31,43,47]$. The underground magma channels in Cerro Azul do not surround the caldera but extend to the south-east. From the locations of the underground magma source and the spewing rifts, as well as the lava lake shown in Figure 6, we infer that the dyke surrounding the eastern and south-eastern vent is extremely fragile where magma intrusions tend to take place. We propose that the area, where dense magmatic channels are centered underground from the caldera to the east and south-east slope and plain, should be crucially evaluated for volcanic hazard if subsequent volcanic susceptibility of Cerro Azul analysis will be made. 


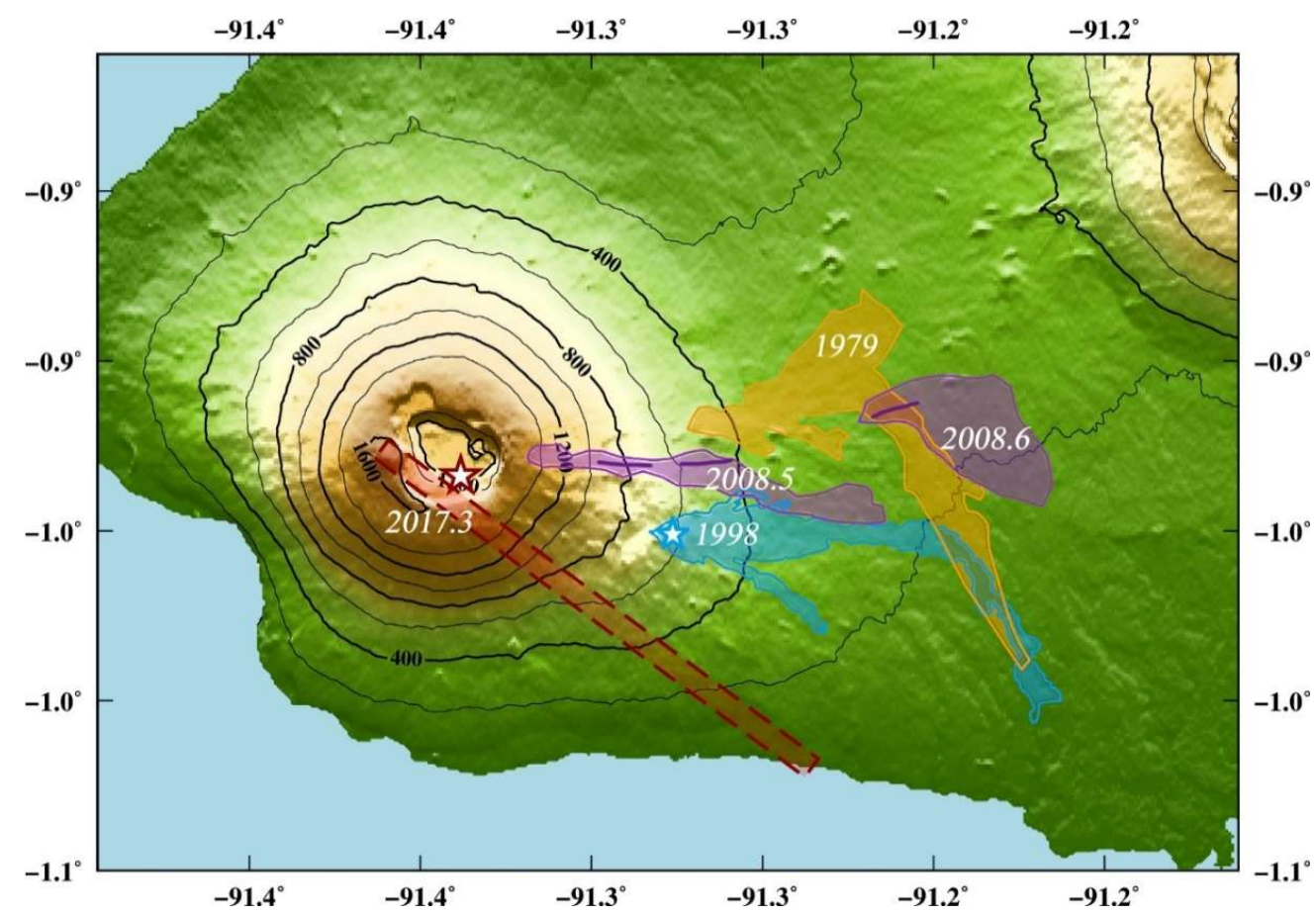

Figure 6. Lava lakes produced by Cerro Azul in 1979, 1998 and 2008 events. The red pentagram and dashed rectangle represent the underground magma sources projected on the surface for the March 2017 unrest event in interferogram IV. Purple areas mark the two lava flow areas from May to June 2008, deep purple curves represent the locations of magma rifts for these two eruptions [49], the blue area marks the lava lake basin erupted from September to October 1998, the blue pentagram marks the approximate location of the presumed magma rift [31,75], and the yellow area represents the presumed lava flows from the eruption event in $1979[31,76]$.

\section{Conclusions}

In this paper, we analysed the surface deformation fields and speculated on the underground source deformation models and the magma transport mechanism for the unrest event at the Cerro Azul volcano, Galápagos Archipelago, South America, from 18 March to 25 March, 2017, using InSAR observations from the Sentinel-1A satellite. We inverted the location and pattern parameters of the underground deformation sources, simulating the structure as a joint model consisting of a point Mogi source and a rectangular platform-shaped Sill source. The Mogi source, located approximately 5-6 km bsl below the caldera, accumulated magma before the tectonic activity began, and the Sill extended from the caldera to the south-eastern plain at the similar depth.

The inversion shows that the magma was released from the Mogi source into the Sill source during the co-unrest period, flowing south-eastward through the long platform-shaped channel and resulting in the overall contraction of the caldera and surface uplift of the south-eastern plain. The volume of flowing magma reached $6 \times 10^{7} \mathrm{~m}^{3}$ according to the source model during this event. The effects caused by magma delivery and tectonic activity formed " $\infty$ "-shaped surface deformation fields in the western Galápagos Archipelago.

Finally, we combined our results with three previous eruption events that occurred in Cerro Azul over the past 40 years, comparing the recorded eruptions and emitting rifts with the positions of the joint models during this unrest activity. Considering that the underground areas east and south-east of the caldera are densely penetrated with magma channels and rifts where tectonic activity and lava eruption events have occurred, we proposed the qualitative reference of areas liable to undergo magma intrusion events underground on the eastern and south-eastern slope and plain-where complex assessment of volcanic hazards exceeds the scope of the study. 
Author Contributions: Conceptualization, C.X.; Formal Analysis, Q.G. and Y.W.; Methodology, Y.W., Y.L. and G.X.; Writing-Original Draft, Q.G.; Writing-Review \& Editing, C.X., Y.W., Y.L. and G.X.

Funding: This work is co-supported by the National Key R\&D Program of China under Grant No. 2018YFC1503604, the National Natural Science Foundation of China under Grant Nos. 41431069, 41774011, 41721003, 41874011 and 41861134009, and the National Key Basic Research Development Program (973 Program) under Grant No. 2013CB733304.

Acknowledgments: The authors thank three anonymous reviewers for their constructive comments. The Sentinel-1A SAR data were provided by the ESA through Sentinels Scientific Data Hub. Most of figures were plotted using Generic Mapping Tools (GMT v.5.4.1) software.

Conflicts of Interest: The authors declare no conflict of interest.

\section{Appendix A}
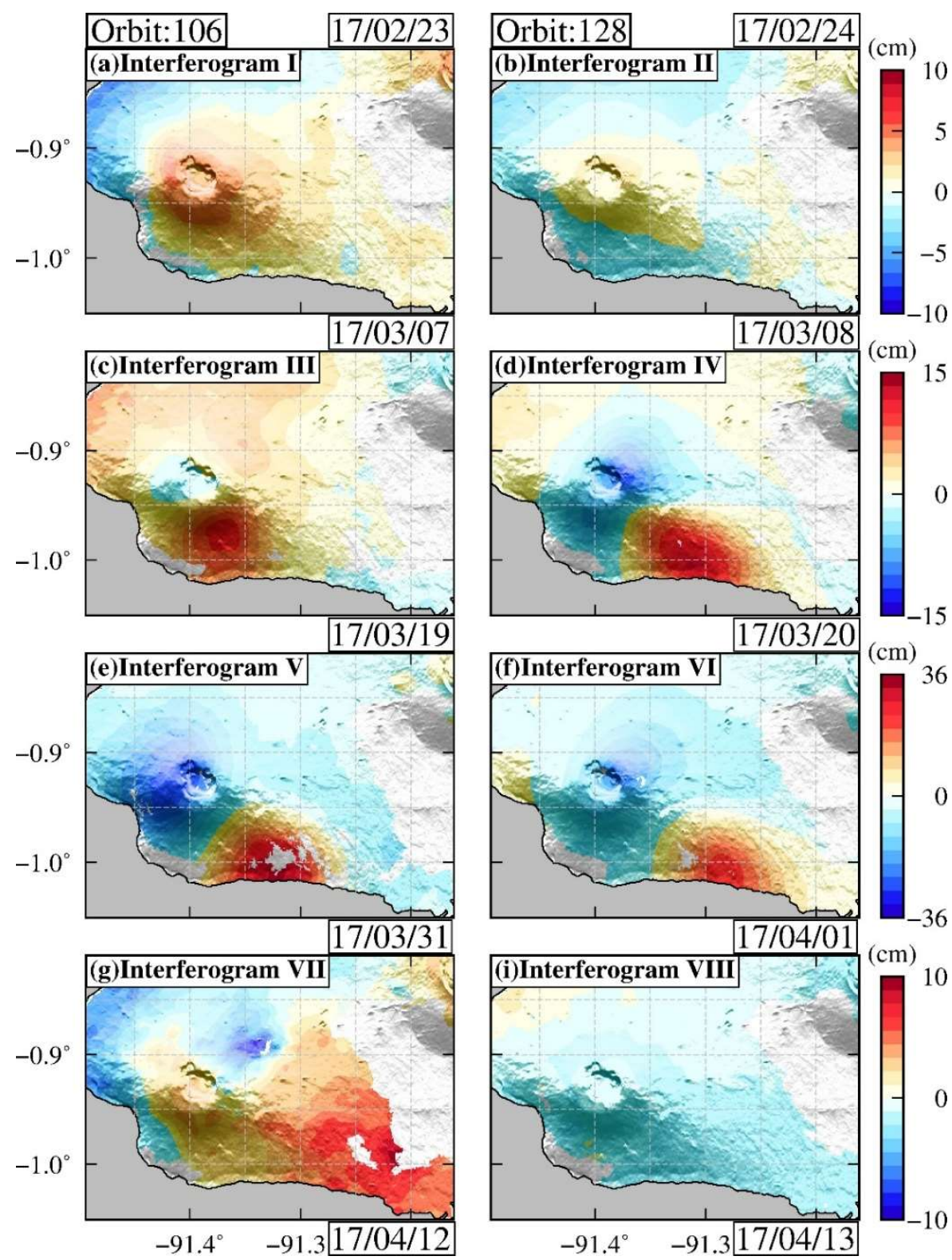

Figure A1. Unwrapped surface deformation fields from Sentinel-1A satellite observations in the Cerro Azul volcano area from 23 February to 13 April. The annotations are the same as in Figure 2. 

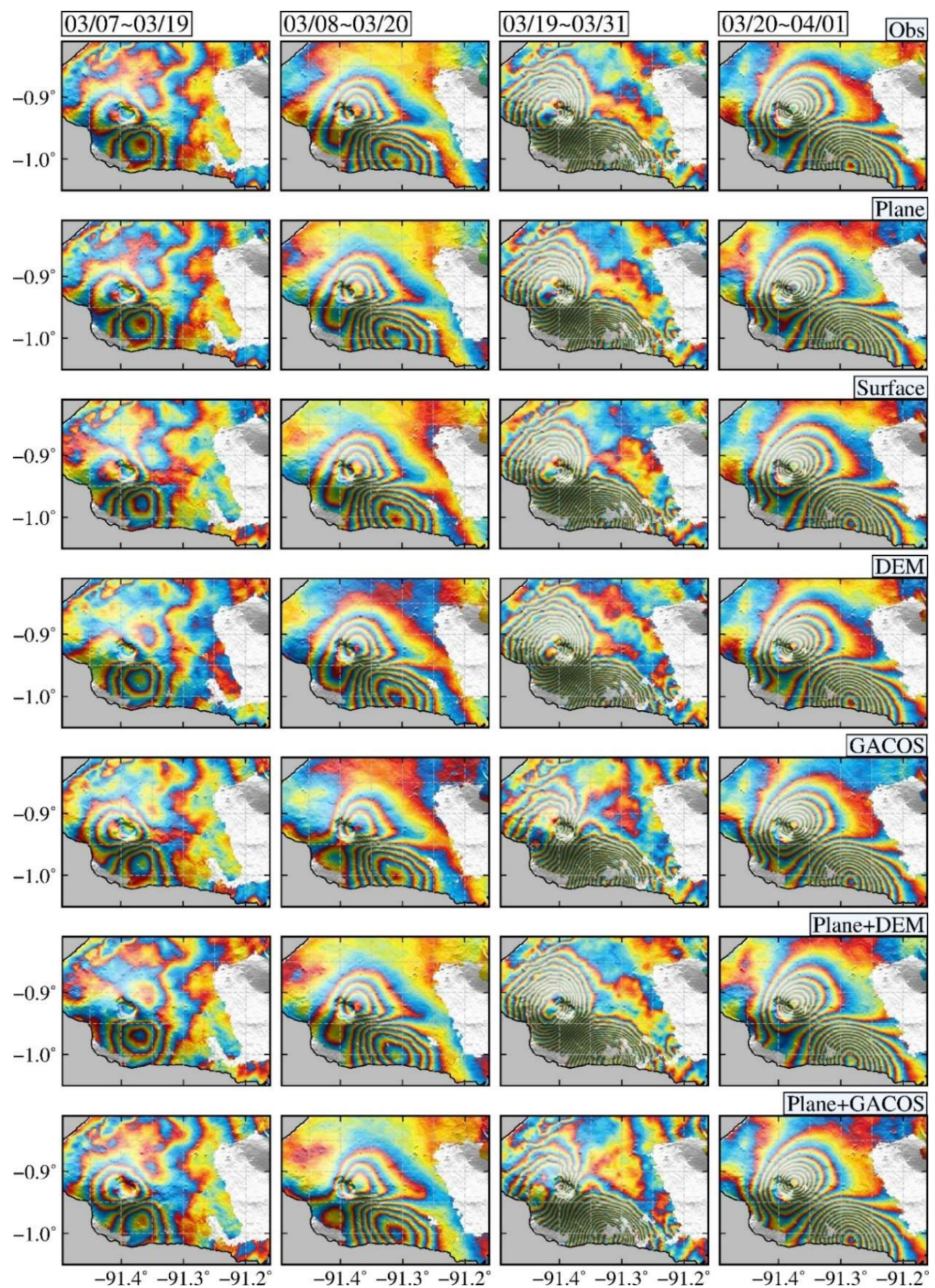

Figure A2. Six correction models with different combinations of parameters and coefficients removing the satellite orbit ramp and atmospheric delay from interferograms III-VI. Four columns represent four interferograms. Seven rows from top to bottom represent different correction models, which are: Obs: Observed data originally; Plane: Orbit ramp corrected by a plane; Surface: Orbit ramp corrected by a surface; DEM: Atmospheric delaying corrected by linear correlated with the digital elevation model (DEM); GACOS: Atmospheric delaying corrected by Generic Atmospheric Correction Online Service for InSAR (GACOS); Plane+DEM: Orbit ramp corrected by a plane and atmospheric delaying corrected by linear correlated with the DEM; and Plane+GACOS: Orbit ramp corrected by a plane and atmospheric delaying corrected by GACOS. 
Table A1. Estimated standard deviations for different corrected interferograms (in $\mathrm{cm}$ ).

\begin{tabular}{cccccccc}
\hline Interferogram & Observation & Plane ${ }^{\dagger}$ & $\begin{array}{c}\text { Quadric } \\
\text { Surface } \ddagger\end{array}$ & DEM $\S$ & GACOS * & $\begin{array}{c}\text { Plane } \\
\text { +DEM }\end{array}$ & $\begin{array}{c}\text { Plane } \\
\text { +GACOS }\end{array}$ \\
\hline III & 3.93 & 3.95 & 2.85 & 3.87 & 3.72 & 3.91 & 3.75 \\
IV & 0.81 & 0.84 & 0.74 & 0.83 & 0.97 & 0.82 & 0.99 \\
V & 3.12 & 3.07 & 2.41 & 2.77 & 3.68 & 2.89 & 3.87 \\
VI & 0.86 & 0.88 & 0.84 & 0.87 & 1.29 & 0.90 & 1.16 \\
\hline
\end{tabular}

${ }^{\dagger}$ Plane: orbit ramp corrected by a plane. ${ }^{\ddagger}$ Quadric Surface: orbit ramp corrected by a surface. ${ }^{\S}$ DEM: atmospheric delaying corrected by linear correlated with the digital elevation model (DEM). ${ }^{*}$ GACOS: atmospheric delaying corrected by GACOS. ${ }^{\dagger+}$ Plane+DEM: orbit ramp corrected by a plane and atmospheric delaying corrected by linear correlated with the DEM. \# Plane+GACOS: orbit ramp corrected by a plane and atmospheric delaying corrected by GACOS.

\section{References}

1. Biggs, J.; Ebmeier, S.K.; Aspinall, W.P.; Lu, Z.; Pritchard, M.E.; Sparks, R.S.J.; Mather, T.A. Global link between deformation and volcanic eruption quantified by satellite imagery. Nat. Commun. 2014, 5, 3471. [CrossRef] [PubMed]

2. Acocella, V.; Di Lorenzo, R.; Newhall, C.; Scandone, R. An overview of recent (1988 to 2014) caldera unrest: Knowledge and perspectives. Rev. Geophys. 2015, 53, 896-955. [CrossRef]

3. Biggs, J.; Pritchard, M.E. Global volcano monitoring: What does it mean when volcanoes deform? Elements 2017, 13, 17-22. [CrossRef]

4. Fernández, J.; Pepe, A.; Poland, M.P.; Sigmundsson, F. Volcano Geodesy: Recent developments and future challenges. J. Volcanol. Geotherm. Res. 2017, 344, 1-12. [CrossRef]

5. Sparks, R.S.J.; Biggs, J.; Neuberg, J.W. Monitoring volcanoes. Science 2012, 335, 1310-1311. [CrossRef] [PubMed]

6. Galetto, F.; Bagnardi, M.; Acocella, V.; Hooper, A. Noneruptive unrest at the caldera of Alcedo volcano (Galápagos Islands) revealed by InSAR data and geodetic modeling. J. Geophys. Res. Solid Earth 2019, 124, 3365-3381. [CrossRef]

7. Giudicepietro, F.; Macedonio, G.; Martini, M. A physical model of sill expansion to explain the dynamics of unrest at calderas with application to Campi Flegrei. Front. Earth Sci. 2017, 5, 54. [CrossRef]

8. Segall, P. Magma chambers: What we can, and cannot, learn from volcano geodesy. Philos. Trans. R. Soc. London A 2019, 377. [CrossRef] [PubMed]

9. Tizzani, P.; Castaldo, R.; Zeni, G.; Lanari, R.; Battaglia, M.; Pepe, A. Magma and fluid migration at Yellowstone Caldera in the last three decades inferred from InSAR, leveling, and gravity measurements. J. Geophys. Res.-Solid Earth 2015, 120, 2627-2647. [CrossRef]

10. Traglia, F.D.; Battaglia, M.; Nolesini, T.; Lagomarsino, D.; Casagli, N. Shifts in the eruptive styles at Stromboli in 2010-2014 revealed by ground-based InSAR data. Sci. Rep. 2015, 5, 13569. [CrossRef] [PubMed]

11. Cannavò, F.; Camacho, A.G.; Gonzalez, P.J.; Mattia, M.; Puglisi, G.; Fernández, J. Real time tracking of magmatic intrusions by means of ground deformation modeling during volcanic crises. Sci. Rep. 2015, 5, 10970. [CrossRef] [PubMed]

12. Sigmundsson, F.; Hreinsdóttir, S.; Hooper, A.; Árnadóttir, T.; Pedersen, R.; Roberts, M.J.; Óskarsson, N.; Auriac, A.; Decriem, J.; Einarsson, P.; et al. Intrusion triggering of the 2010 Eyjafjallajökull explosive eruption. Nature 2010, 468, 426-430. [CrossRef] [PubMed]

13. Zhou, S.; Wu, Y. Earthquake geodesy for fifty years-Thinking on subject development. Geod. Geomat. Chn. 2013, 33, 22.

14. Xu, W.; Jónsson, S.; Ruch, J.; Aoki, Y. The 2015 Wolf volcano (Galápagos) eruption studied using Sentinel-1 and ALOS-2 data. Geophys. Res. Lett. 2016, 43, 9573-9580. [CrossRef]

15. Schaefer, L.N.; Di Traglia, F.; Chaussard, E.; Lu, Z.; Nolesini, T.; Casagli, N. Monitoring volcano slope instability with Synthetic Aperture Radar: A review and new data from Pacaya (Guatemala) and Stromboli (Italy) volcanoes. Earth-Sci. Rev. 2019, 192, 236-257. [CrossRef]

16. Bagnardi, M.; Amelung, F. Space-geodetic evidence for multiple magma reservoirs and subvolcanic lateral intrusions at Fernandina Volcano, Galápagos Islands. J. Geophys. Res. 2012, 117. [CrossRef] 
17. Bagnardi, M.; Hooper, A. Inversion of surface deformation data for rapid estimates of source parameters and uncertainties: A Bayesian approach. Geochem. Geophys. Geosyst. 2018, 19, 2194-2211. [CrossRef]

18. Xu, C.; Gong, Z.; Niu, J. Recent developments in seismological geodesy. Geod. Geodyn. 2016, 7, 157-164. [CrossRef]

19. Di Traglia, F.; Ciampalini, A.; Pezzo, G.; Battaglia, M. Synthetic Aperture Radar and natural hazards: Applications and outlooks. Front. Earth Sci. 2019, 7, 191. [CrossRef]

20. Harpp, K.S.; Mittelstaedt, E.; D'Ozouville, N.; Graham, D.W. The Galápagos: A Natural Laboratory for the Earth Sciences; American Geophysical Union: Washington, DC, USA, 2014.

21. Elliott, J.R.; Nissen, E.K.; England, P.C.; Jackson, J.A.; Lamb, S.; Li, Z.; Parsons, B.; Oehlers, M. Slip in the 2010-2011 Canterbury earthquakes, NewZealand. J. Geophys. Res. 2012, 117. [CrossRef]

22. Global Volcanism Program (GVP), Report on Cerro Azul (Ecuador)—22 March-28 March 2017. Available online: https://volcano.si.edu/showreport.cfm?doi=GVP.WVAR20170322-353060 (accessed on 26 June 2019).

23. Informe Especial Cerro Azul, No. 2-2017-Instituto Geofísico-EPN. Available online: https://www.igepn. edu.ec/servicios/noticias/1473-informe-especial-cerro-azul-no-2-2017 (accessed on 26 June 2019).

24. Informe Especial Cerro Azul, No. 3-2017-Instituto Geofísico-EPN. Available online: https://www.igepn. edu.ec/servicios/noticias/1477-informe-especial-cerro-azul-n-3-2017 (accessed on 26 June 2019).

25. McBirney, A.R.; Williams, H. Geology and Petrology of the Galapagos Islands; Geological Society of America: Boulder, CO, USA, 1969.

26. Canales, J.P.; Dañobeitia, J.J.; Detrick, R.S.; Hooft, E.E.E.; Bartolomé, R.; Naar, D.F. Variations in axial morphology along the Galápagos spreading center and the influence of the Galápagos hotspot. J. Geophys. Res. 1997, 102, 27341-27354. [CrossRef]

27. Canales, J.P.; Ito, G.; Detrick, R.S.; Sinton, J. Crustal thickness along the western Galápagos spreading center and the compensation of the Galápagos hotspot swell. Earth Planet. Sci. Lett. 2002, 203, 311-327. [CrossRef]

28. Werner, R.; Hoernle, K.; Barckhausen, U.; Hauff, F. Geodynamic evolution of the Galápagos hot spot system (central East Pacific) over the past $20 \mathrm{~m}$. y.: Constraints from morphology, geochemistry, and magnetic anomalies. Geochem. Geophys. Geosyst. 2013, 4. [CrossRef]

29. Mittelstaedt, E.; Soule, S.; Harpp, K.; Fornari, D.; McKee, C.; Tivey, M.; Geist, D.; Kurz, M.D.; Sinton, C.; Mello, C.; et al. Multiple expressions of plume-ridge interaction in the Galápagos: Volcanic lineaments and ridge jumps. Geochem. Geophys. Geosyst. 2012, 13. [CrossRef]

30. Geist, D.; Naumann, T.; Larson, P. Evolution of Galápagos magmas: Mantle and crustal fractionation without assimilation. J. Petrol. 1998, 39, 953-971. [CrossRef]

31. Naumann, T.; Geist, D. Physical volcanology and structural development of Cerro Azul Volcano, Isabela Island, Galápagos: Implications for the development of Galápagos-type shield volcanoes. Bull. Volcanol. 2000, 61, 497-514.

32. Hooft, E.E.E.; Toomey, D.R.; Solomon, S.C. Anomalously thin transition zone beneath the Galápagos hotspot. Earth Planet. Sci. Lett. 2003, 216, 55-64. [CrossRef]

33. Gibson, S.A.; Geist, D. Geochemical and geophysical mapping of lithospheric thickness variations beneath Galápagos. Earth Planet. Sci. Lett. 2010, 300, 275-286. [CrossRef]

34. Villagómez, D.R.; Toomey, D.R.; Geist, D.J.; Hooft, E.E.E.; Solomon, S.C. Mantle flow and multistage melting beneath the Galápagos hotspot revealed by seismic imaging. Nat. Geosci. 2014, 7, 151-156. [CrossRef]

35. White, W.M.; Mcbirney, A.R.; Duncan, R.A. Petrology and geochemistry of the Galápagos Islands: Portrait of a pathological mantle plume. J. Geophys. Res. Solid Earth 1993, 98, 19533-19563. [CrossRef]

36. Feighner, M.A.; Richards, M.A. Lithospheric structure and compensation mechanisms of the Galápagos Archipelago. J. Geophys. Res. Solid Earth 1994, 99, 6711-6729. [CrossRef]

37. Mouginis-Mark, P.J.; Rowland, S.K.; Garbeil, H. Slopes of western Galapagos volcanoes from airborne interferometric radar. Geophys. Res. Lett. 2013, 23, 3767-3770. [CrossRef]

38. Rowland, S.K.; Munro, D.C. Caldera morphology in the western Galápagos and implications for volcano eruptive behavior and mechanisms of caldera formation. J. Volcanol. Geotherm. Res. 1996, 72, 85-100.

39. Amelung, F.; Jónsson, S.; Zebker, H.; Segall, P. Widespread uplift and 'trapdoor' faulting on Galápagos volcanoes observed with radar interferometry. Nature 2000, 407, 993-996. [CrossRef] [PubMed]

40. Geist, D.J.; Fornari, D.J.; Kurz, M.D.; Harpp, K.S.; Soule, S.A.; Perfit, M.R.; Koleszar, A.M. Submarine Fernandina: Magmatism at the leading edge of the Galápagos hot spot. Geochem. Geophys. Geosyst. 2013, 7. [CrossRef] 
41. Geist, D.J.; Harpp, K.S.; Naumann, T.R.; Poland, M.P.; Chadwick, W.W.; Hall, M.; Rader, E. The 2005 eruption of Sierra Negra volcano, Galápagos, Ecuador. Bull. Volcanol. 2008, 70, 655-673. [CrossRef]

42. Chadwick, W.W.; Geist, D.J.; Poland, M.; Jónsson, S.; Johnson, D.J.; Meertens, C.M. A volcano bursting at the seams: Inflation, faulting, and eruption at Sierra Negra volcano, Galapagos. Geology 2006, 34, 1025-1028. [CrossRef]

43. Chadwick, W.W.; Jonsson, S.; Geist, D.J.; Poland, M.P.; Johnson, D.J.; Batt, S.; Harpp, K.S.; Ruiz, A. The May 2005 eruption of Fernandina volcano, Galápagos: The first circumferential dike intrusion observed by GPS and InSAR. Bull Volcanol. 2011, 73, 679-697. [CrossRef]

44. Poland, M.P. Contrasting Volcanism in Hawai'i and the Galápagos. In The Galápagos: A Natural Laboratory for the Earth Sciences; Harpp, K.S., Mittelstaedt, E., d'Ozouville, N., Graham, D.W., Eds.; American Geophysical Union: Washington, DC, USA, 2014; pp. 5-26.

45. Davidge, L.; Ebinger, C.; Ruiz, M.; Tepp, G.; Amelung, F.; Geist, D.; Coté, D.; Anzieta, J. Seismicity patterns during a period of inflation at Sierra Negra volcano, Galápagos ocean island chain. Earth Planet. Sci. Lett. 2017, 462, 169-179. [CrossRef]

46. Pepe, S.; Castaldo, R.; De Novellis, V.; De Luca, C.; Casu, F.; Sansosti, E.; Tizzani, P.; D'Auria, L. New insights on the 2012-2013 uplift episode at Fernandina volcano (Galápagos). Geophys. J. Int. 2017, 211, 695-707. [CrossRef]

47. Global Volcanism Program (GVP). Volcanoes of the World, v. 4.8.0. Venzke, E., Ed.; Smithsonian Institution. Available online: https://doi.org/10.5479/si.GVP.VOTW4-20132013 (accessed on 26 June 2019).

48. Farr, T.; Rosen, P.; Caro, E. The shuttle radar topography mission. Rev. Geophys. 2000, 45, 37-55. [CrossRef]

49. Global Volcanism Program (GVP). Report on Cerro Azul (Ecuador). Bulletin of the Global Volcanism Network; Wunderman, R., Ed.; Smithsonian Institution. Available online: https://doi.org/10.5479/si.GVP.BGVN200805353060 (accessed on 26 June 2019).

50. ESA. Sentinel-1 User Handbooks; ESA: Paris, France, 2013.

51. Wegmüller, U.; Werner, C.; Strozzi, T.; Wiesmann, A.; Frey, O.; Santoro, M. Sentinel-1 support in the GAMMA Software. In Proceedings of the Fringe2015: Advances in the Science and Applications of SAR Interferometry and Sentinel-1 InSAR Workshop, Frascati, Italy, 23-27 March 2015.

52. Wright, T.J.; Gonzalez, P.J.; Walters, R.J.; Hatton, E.L.; Spaans, K.; Hooper, A.J. LiCSAR: Tools for automated generation of Sentinel-1 frame interferograms. In Proceedings of the AGU Fall Meeting, San Francisco, CA, USA, 12-16 December 2016.

53. Scheiber, R.; Moreira, A. Coregistration of interferometric SAR images using spectral diversity. IEEE Trans. Geosci. Remote Sens. 2000, 39, 2179-2191. [CrossRef]

54. Jonsson, S. Fault Slip Distribution of the $1999 \mathrm{Mw} 7.1$ Hector Mine, California, earthquake, estimated from Satellite Radar and GPS measurements. Bull. Seismol. Soc. Am. 2002, 92, 1377-1389. [CrossRef]

55. Hastings, W.K. Monte Carlo sampling methods using Markov chains and their applications. Biometrika 1970, 57, 97-109. [CrossRef]

56. Mosegaard, K.; Tarantola, A. Monte Carlo sampling of solutions to inverse problems. J. Geophys. Res. 1995, 100, 12431-12447. [CrossRef]

57. Wright, T.J. Toward mapping surface deformation in three dimensions using InSAR. Geophys. Res. Lett. 2004, 31, 169-178. [CrossRef]

58. Liu, Y.; Xu, C.; Wen, Y.; He, P.; Jiang, G. Fault rupture model of the 2008 Dangxiong (Tibet, China) Mw 6.3 earthquake from Envisat and ALOS data. Adv. Space Res. 2012, 50, 952-962. [CrossRef]

59. Wen, Y.; Xu, C.; Liu, Y.; Jiang, G. Deformation and source parameters of the $2015 \mathrm{Mw} 6.5$ earthquake in Pishan, western China, from Sentinel-1A and ALOS-2 data. Remote Sens. 2016, 8, 134. [CrossRef]

60. Pritchard, M.E.; Simons, M.; Rosen, P.A.; Hensley, S.; Webb, F.H. Co-seismic slip from the 1995 July $30 \mathrm{Mw}=$ 8.1 Antofagasta, Chile, earthquake as constrained by InSAR and GPS observations. Geophys. J. Int. 2002, 150, 362-376. [CrossRef]

61. Wright, T.J. Constraining the slip distribution and fault geometry of the Mw 7.9, 3 November 2002, Denali fault earthquake with Interferometric Synthetic Aperture Radar and Global Positioning System data. Bull. Seismol. Soc. Am. 2004, 94, S175-S189. [CrossRef]

62. Hanssen, R.F. High-Resolution water vapor mapping from Interferometric Radar measurements. Science 1999, 283, 1297-1299. [CrossRef] [PubMed] 
63. Kim, J.R.; Lin, S.Y.; Yun, H.W.; Tsai, Y.L.S.; Seo, H.J.; Hong, S.; Choi, Y. Investigation of potential volcanic risk from Mt. Baekdu by DInSAR time series analysis and atmospheric correction. Remote Sens. 2017, 9, 138. [CrossRef]

64. Yu, C.; Li, Z.; Penna, N.T. Interferometric synthetic aperture radar atmospheric correction using a GPS-based iterative tropospheric decomposition model. Remote Sens. Environ. 2018, 204, 109-121. [CrossRef]

65. Yu, C.; Li, Z.; Penna, N.T.; Crippa, P. Generic atmospheric correction model for Interferometric Synthetic Aperture Radar observations. J. Geophys. Res. Solid Earth 2018, 123, 9202-9222. [CrossRef]

66. Yu, C.; Penna, N.T.; Li, Z. Generation of real-time mode high-resolution water vapor fields from GPS observations. J. Geophys. Res. Atmos. 2017, 122, 2008-2025. [CrossRef]

67. Lisowski, M.; Dzurisin, D.; Denlinger, R.P.; Iwatsubo, E.Y. Analysis of GPS-measured deformation associated with the 2004-2006 dome-building eruption of Mount St. Helens, Washington. In A Volcano Rekindled: The Renewed Eruption of Mount St. Helens, 2004-2006; USGS: Reston, VA, USA, 2008.

68. Segall, P. Earthquake and Volcano Deformation; Princeton University Press: Princeton, NJ, USA, 2010.

69. Segall, P. Repressurization following eruption from a magma chamber with a viscoelastic aureole. J. Geophys. Res. Solid Earth 2016, 121, 8501-8522. [CrossRef]

70. Mogi, K. Relations between the eruption of various volcanoes and the deformations of the ground surfaces around them. Bull. Earthq. Res. Inst. 1958, 36, 99-134.

71. Okada, Y. Surface deformation due to shear and tensile faults in a half-space. Bull. Seismol. Soc. Am. 1986, 23, 128.

72. Centre for the Observation and Modelling of Earthquakes, Volcanoes and Tectonics (COMET). Intrusive activity at Cerro Azul volcano, Galápagos Islands (Ecuador). Available online: https://comet.nerc.ac.uk/ intrusive-activity-cerro-azul-volcano-galapagos-islands-ecuador/ (accessed on 26 June 2019).

73. Naumann, T.; Geist, D. Petrology and geochemistry of volcán Cerro Azul: Petrologic diversity among the western Galápagos volcanoes. J. Petrol. 2002, 43, 859-883. [CrossRef]

74. Mouginis-Mark, P.J.; Snell, H.; Ellisor, R. GOES satellite and field observations of the 1998 eruption of Volcan Cerro Azul, Galapagos Islands. Bull. Volcanol. 2000, 62, 188-198. [CrossRef]

75. Rowland, S.K.; Harris, A.J.L.; Wooster, M.J.; Amelung, F.; Garbeil, H.; Wilson, L.; Mouginis-Mark, P.J. Volumetric characteristics of lava flows from interferometric radar and multispectral satellite data: The 1995 Fernandina and 1998 Cerro Azul eruptions in the western Galapagos. Bull. Volcanol. 2003, 65, 311-330. [CrossRef]

76. Teasdale, R.; Geist, D.; Kurz, M.; Harpp, K. 1998 Eruption at Volcán Cerro Azul, Galápagos Islands: I. Syn-Eruptive Petrogenesis. Bull. Volcano 2005, 67, 170-185. [CrossRef]

(C) 2019 by the authors. Licensee MDPI, Basel, Switzerland. This article is an open access article distributed under the terms and conditions of the Creative Commons Attribution (CC BY) license (http://creativecommons.org/licenses/by/4.0/). 